\title{
DOGMA AND EXPERIMENT IN HARVEY'S TIME
}

\author{
BY

\section{A. MORGAN JONES} \\ A Lecture given in the History of Medicine Series at the University of Manchester, November 8, 1956
}

\begin{abstract}
Although William Harvey is usually remembered for his discovery of the circulation of the blood, this is not the only reason for choosing him as the pivot of this lecture: it is also his attitude to truth and knowledge which well exemplifies the spirit of his age, and this spirit is more important than any single discovery, however significant. Harvey was born towards the end of the 16th century (in 1578) and died at the age of 79 in 1657. During the 16th and 17th centuries there were great changes in outlook which transformed the whole complicated structure of mediæval thought to modernism. To appreciate the nature of this change and the spirit of the times in which Harvey lived, it is necessary to develop at least an outline picture of the attitude of mediæval man to truth and knowledge for these ideas existed into Harvey's time and in some respects well beyond it.
\end{abstract}

\section{Medieval Scholasticism}

At the beginning of the 12th century Christian beliefs were dominated by the Early Fathers of the Church, such as St. Augustine. But during the 12th century there came a revival of intellectual and spiritual curiosity which was influenced by a renewed interest in the rational philosophy of Aristotle. This renaissance of thought threatened the authority of the Church for it began to set reason against faith. In this crisis, a 13th century Dominican friar, Thomas Aquinas, came to the rescue and, by reconciling the rival claims of faith and reason in a great ideological synthesis, maintained the supremacy of the Church and harmonized its beliefs with the philosophy of Aristotle. In his system the Church was still the basis of all-it was established by God and endowed with a head in the person of Peter whose authority was transmitted from age to age through each successive Pope. Its function was to guide man, by its teaching and worship, to his eternal home. Upon these premises Thomas Aquinas erected a logical ideology which covered every aspect of human life. All knowledge and all values were within his province, and he gave answers to all human problems: he was concerned with vitally important things-with conduct and duty, with law and government, with morals and marriage and, of course, in the end with the soul and salvation. Every point is rationally argued in the terms of formal logic. Thomas Aquinas was not ignorant of the possibility of experiment, nor of the value of experience, but to simplify his immense task he deliberately chose to base his work on authority, and to ignore experimental evidence and deduction from observed facts. Although his views are still the subject of controversy, he achieved a great code of human values and conduct, abounding in common sense. With good reason Pope Leo XIII proclaimed it in 1879 the official philosophy of the Roman Catholic Church, though it had for long been unofficially accepted.

The sort of truth that interested Thomas Aquinas was essentially different from the truth that science seeks. His world " presented man as shut up in himself-surrounded by self-conditioned ideas or divine revelations" (Mumford). The external natural world was of interest only in relation to man's destiny. He was not interested in " how" natural phenomena take place, which is the concern of science, but in " why" they exist. This was the natural outcome of his attitude, for he believed that knowledge was stationary-not progressive-so he sought for understanding and not new knowledge. Indeed he feared that any attempt to discover new facts might only 448 
mislead. When Galileo, in Harvey's time, showed that the milky way was composed of an enormous number of stars (and not meteors as Aristotle had declared) Francesco Sizi, a distinguished Florentine divine, refused to confirm this by looking through Galileo's telescope lest he deceive himself; for, Francesco argued, if Galileo saw what could not exist, there must be optical defects in his telescope.

In mediæval times there existed, side by side with the close-knit philosophy of Thomas Aquinas, a rich pattern of subjective fantasies, which made up the popular world-picture of the Middle Ages. Of these Lewis Mumford wrote in The Condition of Man- "The stars that interested mediæval man were not nature's stars, but the stars of astrological lore: stars that guided the Magi to Bethlehem or foretold one's luck in love or war. The four points of the compass were not just geographical directions: they pointed to a mystical arithmetic: there was a mysterious connection with the four elements, air, earth, water and fire; with the four rivers of paradise, with the four winds, with the four humours of the body, and with the four cardinal virtues of the soul. The four sciences of the Quadrivium [arithmetic, geometry, music, and astronomy] plus the three sciences of the Trivium [grammar, rhetoric, and logic] produced seven: both three and four, magical in themselves, had magical consequences: the seven planets, the seven virtues, the seven deadly sins, the seven tones of the Gregorian chant all exhibited this secret correspondence between thoughts and things. Even Thomas Aquinas pointed out at length the exquisite fitness of the seven sacraments, which corresponded to the seven ages of man."

Yet there was throughout the Middle Ages some conflict between the rich fantasy of inner thought and the daily experience of man. For this was an age of craftsmanship: the great mediæval cathedrals are alone sufficient witness of that. The craftsman, "in struggling with obdurate materials, melting and colouring glass, hammering iron, hewing stone, and beating copper, must have learnt that practical knowledge could be gained by experience, and prayer would work only if its efficacy was added to the intelligent manipulation of materials." This, Mumford writes, was the daily lesson of craftsmanship. It is perhaps because of the effect of manual skill upon thought that there was so much opposition to practical methods in medicine in the Middle Ages. It was this that was responsible for the unwillingness of anatomists to do their own dissection-a reluctance that generally existed until the 16th century. In the 12th century the University of Paris expelled physicians who worked with their hands. Students of medicine could not let blood or perform any sort of operation and both surgery and dentistry were in disrepute. Mumford believes that this separation of the hand and the mind, which existed for many centuries, has done mischief that still exacts a toll today. He wrote: "the glorified garage mechanic, the pompous faith healer, and the mental dissectionist who treats diseases, not human beings-all these are still witness to the ancient quarrel between the unhandy minds and the unminded hands of the 17th century." We have only to look around in our daily work to recognize that there is some truth in this. Indeed, until the last year or two the roll of our hospital medical board continued to give mediæval precedence to the " unhandy minds" over the " unminded hands."

But it would be a mistake to believe that mediæval dogma and logic did only harm in obstructing the development of experimental science. In Science in the Modern World Whitehead wrote " the habit of exact thought was implanted in the European mind by the long dominance of scholastic logic and scholastic divinity. The habit remained long after the philosophy had been repudiated, the priceless habit of looking for an exact point and of sticking to it when found. Galileo owes more to Aristotle than appears on the surface of his Dialogues: he owes to him his clear head and his analytic mind." And more than that, for mediævalism contributed to science an ineradicable belief that " every detailed occurrence can be correlated with its antecedents in a perfectly definite manner, exemplifying general principles. Without this belief the incredible labours of scientists would be without hope" (Whitehead).

This is the background of mediæval thought which exerted so great an influence upon men's minds into the time of Harvey: it was both the foundation upon which he had to build, and the prison from which he sought to escape. 


\section{ENGLAND IN THE 16TH Century}

But what of the English social, political, and intellectual environment into which Harvey was born in the 20th year of Elizabeth's reign? I despair of trying to summarize in a few sentences the story of England in the 16th century; I know that I shall be forced into those broad generalizations that historians so rightly condemn, yet seem so unable to resist. So I may as well begin with one from the pen of a distinguished historian. In Tudor England Bindoff described the state of the country in 1558, when Mary died, as " politically bankrupt, spiritually impoverished, economically anarchic, and intellectually enervated." The scene was, in fact, still strewn with the debris of the great creative upheaval in the reign of Henry VIII.

For two centuries England celebrated November 17, for it was on this day in 1558 that Elizabeth, the last child of Henry VIII, became Queen at the age of 25. To her political genius and her judgment of men, the England of Harvey's early years owed a great deal. Under her prosperity slowly returned, and Elizabeth assisted recovery by wise measures. First she restored the coinage, surprisingly, it is said, at a profit to her Treasury. Then came the Statute of Artificers, a great code of labour, which laid down the universal obligation to work and enacted a period of seven years apprenticeship in the skilled trades, so raising the standard of workmanship and increasing the pool of labour. The problem of the poor she dealt with by laws governing the collection and distribution of relief. In this way, the State took over economic life from the Guilds and charity from the Church much as it had earlier taken over government from the feudal barons.

The social and political achievements of the 16th century are not very obviously connected with the extraordinary progress that was made in literature, art, architecture, and music, for this was a development of the Renaissance on the continent and, like Harvey's own work, owed much to Italian influence. With the English Renaissance came the poetry of Michael Drayton (1563-1631) and Edmund Spenser (1552-99), the drama of William Shakespeare (1564-1616) and Christopher Marlowe (1564-93), and the prose of Francis Bacon (1561-1626), Richard Hooker (1554-1600), and Walter Raleigh (1552?-1618), to mention only a few. In 1563 the first English book on architecture was published-John Shutes' Chief Groundes of Architecture-and the building of fine houses flourished as never before. English music achieved a contemporary reputation it has never since regained, though most of the composers of that time are now forgotten. Under Elizabeth the growth of prosperity and confidence in the future contributed to a new unity from which the spirit of a nation emerged-and with it came a willingness to adventure and an urge to explore new places. The exploits of Elizabethan seamen, such as Hawkins, Drake, Grenville, and Frobisher, have grown into legends. This adventurous spirit had a parallel in thought, for there was a greater willingness to turn outward from the inner philosophy of mediæval times to explore the secrets of nature, and a surer belief that new knowledge of significance could be gained by observation and experiment. But the regression of mediæval concepts was very slow and it was not until almost a century after Harvey's birth that Boyle in his Sceptical Chymist (published in 1661) challenged the mediæval idea that all physical objects were made of a combination of two or more of the elements earth, air, fire, and water. Nor did Francis Bacon, a distinguished Elizabethan, ever accept the early 16 th century view of Copernicus that the earth rotated round the sun.

This was the English environment into which Harvey was born at Folkstone in 1578: a new spirit of exploration of things material and things of the mind was abroad, but the hold of mediæval ideas, although slackening, was still a power to be reckoned with.

\section{HARVEY's EDUCATION}

At the age of 10, Harvey entered the Grammar School of Canterbury in the year in which the Spanish Armada was destroyed. Most of the grammar schools of the time had been founded to replace the educational facilities that had been destroyed by the dissolution of the monasteries after 1530. The teaching they gave was confined mainly to Latin, Greek, and Hebrew, the three languages necessary for biblical study and theological controversy. Harvey was certainly an able Latin scholar and it is said that Virgil was his favourite author. In 1593, at the age of 16 , he obtained 
a scholarship to Caius College, Cambridge, and took his B.A. degree in 1597. Harvey was fortunate in the time he went to Cambridge for between 1530 and 1560 Oxford and Cambridge went through a difficult time, their wealth and numbers being greatly reduced by the disappearance of the monks and friars after the dissolution of the monasteries and by the subsequent economic difficulties of the country. But in Elizabeth's reign a new and more secular Oxford and Cambridge grew up, much freer from mediævalism; many undergraduates were destined for lay careers and the most prominent men of the time had studied at Oxford or Cambridge. The college system was replacing hostelries and lodging houses and, although there were no official tutors, private contracts were made with Fellows on the master and apprentice basis. Unfortunately, the services given by Fellows often depended more upon the wealth of the parents than the ability of their offspring! But the Church still had great influence, and the Dons were compelled to take Holy Orders and to remain unmarried; attendance at College Chapel was enforced on all. Today universities are amongst the main sources of new ideas, but in Harvey's time they were strongholds of resistance against the unorthodox.

When Harvey left Cambridge and came to consider his medical education it was natural that he should think of Padua, for at that time its medical school justly enjoyed an unrivalled reputation, and many distinguished English physicians had studied there. At Padua, between 1598 and 1602, Harvey must have become familiar with current ideas upon the movement of the blood. Galen was still the paramount authority, and Harvey in his writings shows his deep, even exaggerated, respect for Galen's views. Galen believed that the portal venous system carried materials from the alimentary tract to the liver, where blood was formed and charged with natural spirits. In the hepatic veins the blood ebbed and flowed between the liver and the right ventricle. A little penetrated drop by drop through pores in the ventricular septum, to meet in the left ventricle air containing vital spirits drawn from the lungs by the pulmonary veins. The combination of the blood with vital spirits in the left ventricle led to the production of heat, and the function of the lungs was to dissipate this heat, hence the warmth of the expired air. The blood mixed with vital spirits was distributed to all parts of the body by the arterial system, in which the blood ebbed and flowed. The venous system was centred on the liver, which distributed blood not only to the right ventricle but also to the whole body by ebb and flow in the superior and inferior venæ cavæ. The venous blood, in addition to carrying natural spirits, served to remove waste products from the tissues, and these waste products were discharged from the right ventricle by the pulmonary artery to the lungs.

These ideas explained a great deal of the gross anatomy of the liver, of the portal and systemic venous systems, and of the heart, lungs, and arteries. They explained why the body was warm, why death occurred when breathing stopped, and why this led to coldness of the body. Galen's ideas were so closely knit into an anatomico-physiological concept, which provided explanations for almost all the known facts, that to alter them meant the abandonment of a whole system of physiology, and moreover, a system backed by centuries of authority, embraced by the all-pervading Church, and almost universally accepted by the mediæval world. To criticize it was an act of courage: to put something better in its place was a great achievement.

Amongst Harvey's predecessors it was those who did not accept the mediæval schism between hand and mind who blazed a trail towards the ultimate discovery of the circulation. Leonardo da Vinci (1452-1519) was the first to make accurate drawings of the human heart, its valves and its vessels. He showed the complete occlusion of the ventricles by the auriculo-ventricular valves and, by experiment on a living pig, demonstrated the active contraction of the heart muscle, in contradiction of the Galenical doctrine of passive dilatation. He did not conceive the idea of the circulation of the blood, but likened its flow to the rise and fall of the tide. Leonardo attempted to calculate the outflow of blood from the heart, though erroneously. But the quantitative approach he used was entirely new in his time, and it was subsequently adopted by Harvey in De Motu Cordis.

Vesalius (1514-64) when Professor of Anatomy at Padua, also did his own dissections and came to the conclusion that there was no visible way for blood to pass through the ventricular 
septum. Since he worked within the grasp of the Italian Inquisition, he may not have cared to stress this refutation of Galen's views, and he suggested that the blood "sweated" through the septum. There is, however, some reason to believe that Vesalius committed himself much more strongly in his lectures at Padua than he ever did in writing.

Michael Serveto, born in Navarre, Spain, in 1511, was a theologian but he made a surprising contribution to the circulation in a book on theology (De Restitutio), in which he stated that the blood is driven from the right ventricle to the lungs " where it mingles with the inspired air and is cleansed from its fumes " eventually being "drawn into the left ventricle during its expansion." In 1553, the year in which this was published, Serveto was burnt alive for heresy in Geneva, then a small Protestant republic in which Calvin was virtually dictator: only three copies of his book survived the fire. The Catholic Church also condemned him but, being a week or so too late, had to be content with burning him in effigy! Unfortunately, isolated quotations give a false idea of the precision of Serveto's views on the pulmonary circulation for he believed that the blood was in open communication with the trachea, and his concept of the rest of the movement of the blood was a mediæval fantasy. All his ideas were subservient to his theological doctrines and astrological beliefs and there is no evidence that he ever made any personal observations or experiments; it is possible that, as we shall see, he got his ideas from another source. There is, however, reason to believe that Vesalius saw some manuscript pages of Serveto's Restitutio (Robertson).

When Vesalius was Professor of Anatomy at Padua he had an assistant, Realdo Colombo, a man of comparatively little originality, who published nothing in his life-time, but wrote a text-book of anatomy which was published in 1559 after his death. This has been described as " an almost barefaced imitation of Vesalius" (Foster) but it was certainly clearer, more concise, and didactically superior (Bayon). For this reason anatomists of Harvey's time preferred Colombo to Vesalius and his book contains one paragraph which must have been known to Harvey: "Between the ventricles is a septum through which almost all think there is a way from the right ventricle to the left. ... This, however, is an error for the blood is carried by the arterial vein [pulmonary artery] to the lung. ... . It is brought back, together with air, by the venal artery [pulmonary vein] to the left ventricle of the heart. ..." Although many believe that he got this idea from Serveto, whose book was published six years earlier, it is equally possible that the reverse is true, for Colombo was teaching anatomy in Pisa in 1545, and the earliest known manuscript of Serveto's book was dated 1546. Further, Colombo gave a clear and convincing anatomical account, together with the observations and experiments on which his views were based. Bayon has suggested that Colombo may have got the basic idea from another source for a translation of the 13th-century arabic writings of Ibn an-Nafis (1210-88) was published in Venice in 1547, twelve years before Colombo's book. Ibn an-Nafis knew of the pulmonary circulation for he described how the blood passes through the pulmonary artery " reaches the lungs, spreads in its substance, mixes with the air and flows in the venous artery [pulmonary vein] so as to be sent to the left of the heart ventricles." No one knows how Ibn an-Nafis got his information for he rejected both anatomical examination and experiments on animals. The importance of his writings has become known through the work of Meyerhof in 1935, but it does not seem likely that they influenced Colombo's views, for it is now known that the 1547 translation of his works did not contain the account of the pulmonary circulation.

It has been claimed that a pupil of Colombo, Andrea Cesalpino, anticipated Harvey's discovery of the circulation. It is probable that he adopted Colombo's views on the pulmonary circulation but, as Osler pointed out, Cesalpino believed that blood was distributed through the body by the veins for the nourishment of all its parts, and when a vein was ligatured "the blood behaved like a scared hen and rushed back in the contrary direction." By circulatio he seems to have meant efflux and reflux of the blood in the veins, in conformity with Galen's views. Though it may reasonably be claimed that the character of the pulmonary circulation had been recognized before Harvey's time, and the obstacle of the imperforate ventricular septum overcome, it is equally clear that the circulation from arteries to veins was unrecognized, and the obstacle to the flow of blood between them was regarded as absolute. 
The principal known facts that might at that time have raised doubts were the valves of the heart and of the veins. It must have been difficult to see how the reflux of arterial blood took place through the aortic valve into the left ventricle, and the valves of the veins presented a similar problem. Harvey's attention was drawn to these by Giralomo Fabrizio, Professor of Anatomy in Padua when Harvey studied there. Fabrizio was a very learned man and must have influenced Harvey deeply for the two subjects that Harvey followed throughout his life-the circulation and embryology -were also the principal interests of Fabrizio. He was an able observer and an attractive teacher but in ideas he was gripped by the fetters of tradition, accepting fully the views of Aristotle and Galen. He certainly lectured on the valves of the veins in Harvey's time at Padua, for he first noticed them in 1574 and published his description in 1603. To us it seems obvious that they would prevent the flow of blood to the periphery. As, however, this was incompatible with the views of Galen, Fabrizio assumed that their function was merely to slow down the peripheral flow of blood, and he fully accepted Galen's view of the ebb and flow of venous blood. Robert Boyle (1627-91), well known as a pioneer in chemistry, wrote in 1688 that he had asked Harvey what things induced him to think of the circulation of the blood, and Harvey answered that he had taken notice of the valves in the veins, so placed that they gave free passage to the blood towards the heart, but opposed the contrary way, and "since the blood could not well, because of the interposing valves, be sent by the veins to the limbs, it should be sent through the arteries, and return through the veins, whose valves did not oppose its course that way."

\section{The Discovery of THe Circulation}

So, in 1602, Harvey returned home to England probably familiar with almost all the observations and opinions so far discussed. In the same year he took his Cambridge M.D., in 1604 he was admitted by examination to the Royal College of Physicians, and in 1607 became a Fellow. Two years later he was appointed Assistant Physician at St. Bartholomew's Hospital and soon built up a practice which included many distinguished patients, notably Charles I and Francis Bacon. In 1615 he was appointed Lumleian Lecturer at the Royal College and almost certainly included his concept of the circulation in his first lectures in 1616. He must have developed his idea of the circulation between 1602 and 1616. Amongst the Englishmen of the time, who may have influenced his approach, three stand out: William Gilbert (1544-1603), Robert Fludd (1574-1637), and Francis Bacon (1561-1626).

Francis Bacon, who had advanced ideas and great gifts of exposition, made a profound impression in his own time and on subsequent generations; but he was more philosopher than scientist. He profoundly believed in experiment, but has been described as a " most enthusiastic but futile experimenter." He was modern in his belief in the advancement of knowledge, but clung to many mediæval ideas, some of which had already been refuted by the very methods he advocated. He devised a complete scheme for the experimental investigation of natural phenomena, which neither he nor anyone else ever used. He was a patient of Harvey's and of him Harvey said "He writes philosophy [science] like a Lord Chancellor; I have cured him of it." Although Francis Bacon did so much to propagate ideas about the advancement of knowledge, he did not himself contribute to knowledge in any field, and he seems to have had little or no regard for the work of men like Gilbert and Harvey who did, in fact, advance knowledge by Baconian methods. If we are to believe Harvey, the feeling was mutual.

William Gilbert was a physician of Colchester, but he is known for his work on magnetism. He was President of the Royal College of Physicians in 1600 and died in 1603, the year after Harvey returned to England. He was one of the first really successful experimentalists. He realized that the earth was a huge magnet and devised a primitive compass. Of him Dryden wrote (in somewhat dated lines):

\section{" Gilbert shall live till lodestones cease to draw}

Or British fleets the boundless oceans awe."

He was truly of Harvey's spirit and from him Harvey may have learnt the need to test hypothesis by experiment, and an essential criterion of a good experiment, namely that it can be repeated. 
Robert Fludd was also a physician and a censor of the College on three occasions, although he himself had some difficulty in passing the College examinations. $\mathrm{He}$ was the first practising physician to try to explain pathological processes by experiments, though it has been said that " he drowned his results by much irrelevant speculation." Harvey certainly knew him, and if he gained anything from him, he was also a loser, for he sent De Motu Cordis to Fludd's printers in Germany and a shocking piece of work they made of it.

We can probably safely conclude that Harvey owed much less to his English contemporaries than to his experiences in Padua. It is, of course, impossible to be certain of the way in which Harvey built up the idea of the circulation if, indeed, he himself knew. From what he said to Boyle it is possible that the structure of the venous valves was his starting point. He was very certain of the course of the pulmonary circulation, though he wrongly attributed this observation to Galen. He wrote: "From Galen, that divine man, that Father of Physicians, it clearly appears that the blood passes through the lungs from the venal artery [pulmonary artery] to the small branches of the venal artery [pulmonary vein]." He had clear views on the function of the pulmonary and aortic valves-“" once the blood has entered one of the great arteries it cannot return by the path it came. Its movement in that direction is absolutely stopped by valves."

But it is relatively unimportant how Harvey conceived of the motion of the blood " as it were in a circle." It is much more important to know that he set about testing his hypothesis and to see what methods he used to do so, for it is in this that his claim to greatness lies. Most of those who worked before him had been content with the plausibility of their ideas or sought confirmation only in authority, but Harvey recognized the need to test the truth of his, and by the techniques he chose, he played an important part in laying the foundations of the scientific method. In the first sentence of De Motu Cordis he wrote: “In discussing the movements and functions of the heart and arteries we should first consider what others have said on these matters, and what the common and traditional viewpoint is. Then by anatomical study, repeated* experiment and careful observation we may confirm what is correctly stated, but what is false make right" (Leake translation).

Harvey used two methods of test. First, a quantitative mathematical approach in which he showed that the heart output in half an hour must greatly exceed the total amount of blood in the body. Since, Harvey wrote, the aortic valve prevents reflux into the ventricle, where could so much blood go to, or come from? It could only go to the veins, and thence return to the heart. How it got from the arteries to the veins, Harvey did not know, for the capillaries were not discovered until Malpighi demonstrated them in 1661. Although Harvey's calculations were sketchy and inadequately developed and considerably underestimated the output, they implied a way of thought that only Leonardo had previously used. Secondly, Harvey devised a series of testing experiments which showed the direction of blood flow in the veins, the efficiency of the venous valves, and attempted to show the passage of blood from the arteries to the veins.

A few men in every age from classical Greece and before had sought knowledge by experiment but not much had been gained because most experiments were ill-conceived and inconclusive or misleading. For instance, Galen attempted to demonstrate that the pulsation in an artery is transmitted by its wall and not by the contained blood. To do this he inserted a quill in the artery and found that the pulsation stopped beyond the quill. Bayon suggests that this was because he used a blocked quill and did only one experiment. Harvey made a significant contribution to the experimental method owing to his conviction that to be conclusive experiments must be repeated by the investigator and repeatable by others. Because his experiments were of this kind and because the hypothesis they were designed to test was well conceived, Harvey was able to show that the experimental method was capable of leading to significant advances in knowledge. Harvey's contribution was not so much the conception of experimental investigation, for there were others who had used it before him, but the success which he achieved by the way he used it. Consequently, the way in which Harvey's methods and conclusions came to be accepted is of importance in the development of the scientific method.

* My italics. 


\section{Reactions to "De Motu CoRdis"}

For twelve years, from 1616 to 1628 , Harvey's Lumleian lectures in London almost certainly included a description of the circulation of the blood, but seem to have attracted no attention, although they were attended by many Fellows of the College. De Motu Cordis was published in 1628 in Frankfurt. It was a badly printed book of 72 pages of poor paper which perished in time, so that only 35 copies are now known to exist. After its publication the first printed comment came in 1630 from a Hull physician Primerose whom Harvey had examined as a Censor of the College. Primerose roundly denied the truth of Harvey's work in a book which he wrote in two weeks. The first approval came from Fludd, who may have been prejudiced for he was friendly with Harvey. In 1635 Emilio Paragiano (1567-1643) of Venice also condemned Harvey and wrote of the heart sounds, which Harvey mentioned: "Our poor deaf ears, nor any physician in Venice can hear them; thrice fortunate those in London who can." Descartes, the philosopher (1596-1650) accepted Harvey's views in 1636, though Bayon doubts whether he ever understood them. In 1639 a Venetian physician Folli (1615-50) also accepted Harvey's work but only because he believed that Galen had advanced the same idea. Glisson (1597-1677), when Regius Professor of Physic at Cambridge, is known to have been an early adherent of Harvey. But, in fact, between 1628 and 1640 little criticism or praise was published, and Harvey's work seemed more likely to perish from neglect than from criticism.

After 1640, however, support started to come from Ent in Cambridge and from Holland, where many distinguished physicians were convinced. A series of criticisms then appeared based mainly on the very different appearance of arterial and venous blood, for many found it difficult to believe that they were the same fluid. An interesting conversion was that of Plempius (1601-71) of Louvain who originally criticized Harvey, but later performed some experiments in dogs and subsequently acknowledged that Harvey was correct. This seems to represent a new spirit in science, and one not universally embraced even today! By 1648 prominent men in England, France, Germany, Holland, and even Padua had accepted Harvey's views. In 1651 Nathaniel Highmore wrote the first English anatomical work in which the circulation of the blood was fully recognized; it was appropriately dedicated to Harvey. Like Boston today, Italy, the cradle of so much that was growing in medicine, was hard to convince, but in 1651 the first open Italian support came from a physician of Rome, Giovanni Trullius, whose convincing experiments converted many sceptics. Harvey himself is quoted as saying that no man over forty admitted the truth of the circulation, but he was fortunate enough to live to see a widespread acceptance both of his conclusions and his methods, and the fact that his experiments could be repeated by men like Plempius in Belgium and Trullius in Rome undoubtedly contributed to this happy outcome.

Harvey was not a rebel or a firebrand, but a careful, persistent, and unprejudiced investigator, with an almost exaggerated respect for the views of his predecessors. The methods available in his time for testing physiological hypotheses were few and limited in scope, but such as they were he used them persistently and patiently throughout his life, not only in De Motu Cordis but also in his later work De Generatione. He well represents the age that learnt to loosen the bonds of dogma by experiment and observation. The 17th century has been labelled the century of genius, for it produced such scientists as Boyle and Isaac Newton, such philosophers as Descartes and Spinoza, and men of vision like Francis Bacon, Hobbes, and Liebnitz. It laid the foundations of science, of political freedom and democratic government, of religious toleration, and of freedom of speech. It is not surprising that Whitehead wrote in Science in the Modern World: "A brief and sufficiently accurate description of the intellectual life of the European races during the succeeding two centuries and a quarter up to our own times is that they have been living upon the accumulated capital of ideas provided for them by the genius of the seventeenth century." It is true that there is still no sign of any new development of thought comparable with the radical change of outlook that was beginning to gather force three centuries ago. Although there is no reason to suppose that the potentialities of the scientific method are becoming exhausted, it is obvious that it has limitations which are particularly pertinent in our times when science seems almost as likely 
to destroy our civilization as to enhance it. With Pope we must sometimes be troubled by the contrast between man's increasing power over his environment and his inadequate control over himself

" Go, wondrous creature! mount where Science guides

Go, measure earth, weigh air and state the tides,

Instruct the planets in what orbs to run,

Correct old Time, and regulate the sun;

Go teach Etermal Wisdom how to rule-

Then drop into thyself, and be a fool."

In the words of Bertrand Russell (The Scientific Outlook) "Not all wisdom is new, nor is all folly out of date." Perhaps that is not an inappropriate motto for these lectures.

My debt to Bayon's scholarly articles on Harvey and his contemporaries will be obvious to all familiar with his work (Ann. Sci. (1938) 3, 59, 435, and (1939) 4, 65, 329; Proc. Roy. Soc. Med. (1938), 32, 31; and (1951) 44, 213). An excellent selected bibliography of writings on Harvey has been published by the Wellcome Historical Medical Library (Current Work in the History of Medicine, 1956, 9, 57) and I am indebted to the librarian, Dr. F. N. L. Poynter, for much advice and information. I have used the Leake Translation of De Motu Cordis but I have found it helpful to compare this with the original whenever possible. In a general review of this kind it is neither desirable nor possible to enumerate all the sources consulted but some of the more important are mentioned in the text. 